\title{
Selfie Phenomenon in Muhammadiyah University of Sidoarjo (Phenomenology Approach Study)
}

\author{
Moch. Muqhir, S.Ag \\ Muhammadiyah University of Sidoarjo \\ Email: mughirmusasi@gmail.com / mughirmuda@gmail.com
}

\begin{abstract}
Selfie itself is a form of photographs which is resulted from taking self-portraits that are indeed becoming a phenomenon for the wider community. The selfie phenomenon is currently one of the most booming phenomena at the end of 2013 until now, and certainly one of the readers often does this. The tradition of phenomenology is a tradition that is quite interesting to discuss, phenomenology may be said to reject the theory. This study focuses more on how the presentation of Culture selfie in Indonesia and how the Selfie Phenomenon in the Islamic view. In order to provide knowledge to adolescents and the public about the phenomenon of selfie among the people today. This study uses a phenomenological approach, which is defined as a study in the field of philosophy that studies humans as a phenomenon. The tradition of phenomenology places very strong emphasis on the perceptions and interpretations of human subjective experience. This research has used the elaboration of methods and steps carried out by explorative in describing them using a qualitative approach. This research method used is a qualitative research method, the technique of collecting samples uses the method of exposure to find the research focus about selfie phenomenon in Muhammadiyah University in Sidoarjo. This phenomenon of selfie happened because of the technological developments were so extraordinary. If in the past the photos of self were not possible because of the lackness of capable and supportive technology, now there are many tools that support such as gadgets or cell phones for selfies.
\end{abstract}

Keywords: selfie phenomenon, society, university, Muhammadiyah, approach, phenomenology, technology, photo

\section{A. INTRODUCTION}

Today, technological progress is increasing. This requires the community to follow the flow of increasingly advanced technology. Along with the development of the times, increasingly developed technological tools in people's lives. Cameras that were once a rare item are now in every human grip. This then brought a new phenomenon among the people that was very popular among the millennial generation and also the generation of oldies.

The era is progressing, technology is increasing. This encourages people to continue and always keep up with the times and technology. Along with the development of the era, the technological tools in the life of society are increasingly developing.

The presence of technology such as smartphones such as iPad, iPhone and Android has brought a new phenomenon among teenagers is selfie. Is that selfie? Selfie itself is a form of photographs of the results of taking self-portraits which are indeed becoming a phenomenon for the wider community. When doing so, the selfie will hold the camera phone or camera with one of his hands and aim the lens at the photographed part. 
The selfie phenomenon is currently one of the most booming phenomena at the end of 2013 until now and certainly one of the readers often does this. How selfie becomes a trend for teenagers who like to arouse selfies to social media so that it can be seen by other visitors, even from another point of view many people think that a selfie is a self-identity crisis, because many selfies are associated with teenagers who experience disruption of self-confidence by trying to get the attention of the public using social media.

In a study initiated by Tri Hamingsih which mentions when there is someone who likes to put his photos into social media and that is very dangerous to relationships in real life.

From the above ideas can be interpreted that the impact of style or posing in a photo is very large, because it can show our status. Therefore, how to style or pose accordingly and precisely with our criteria is not to the detriment of us and others. Thus I write this paper so that we know about phenomena taking pictures involves a lot of styles or poses that are currently in trend.

The phenomenology tradition is a tradition that is quite interesting to discuss, phenomenology may be said to reject the theory. Phenomenology is a little allergic to theory.

Phenomenology approach is to illuminate the specific, to identify phenomena through how they are perceived by the actors in a situation. Hence, phenomenology is concerned with the study of experience from the perspective of the individual, 'bracketing' taken-for-granted assumptions and usual ways of perceiving.

This approach emphasizes rationalism and cultural reality that exists. This is in line with ethnographic research which focuses on the views of the local community. Reality is seen as more important and dominant than theories. Phenomenology makes actual experience the main data in understanding reality. What someone can know is what he has experienced.

Based on the background explanation above, this study focuses more on how the presentation of Culture selfie in Indonesia and how the Selfie Phenomenon according to the Islamic view itself. The purpose of this study is to provide knowledge to adolescents and society about the phenomenon of selfie among the people today.

\section{B. RESEARCH METHOD}

This research has used the elaboration of methods and steps carried out by explorative in describing them using a qualitative approach. The researcher has chosen to use this method with the consideration that the case under study was a case that required the use of observations rather than using an extension model, second with qualitative research easier when dealing with reality, and the third was the closeness of the emotional relationship between the researcher and respondent so that in-depth data.

This research has used another qualitative research method with a phenomenology approach. The use of this method is the reason that the focus in this study is Selfie Phenomenon in Society, especially in Muhammadiyah University of Sidoarjo. Meanwhile, the phenomenology approach aims to describe the meaning of life experiences experienced by several individuals, about certain concepts or phenomena, by exploring the structure of human consciousness. So here the researcher wants to know the meaning of the experience experienced by the enthusiasts in Selfie Photo as daily routine whether doing it alone or doing it in a group with friends.

Many experiences are experienced by some individuals, about certain concepts or phenomena, by exploring the structure of human consciousness. So here researchers want to know the meaning of experiences experienced by society that enthusiast related 
to generation $\mathrm{Z}$ culture through this phenomenological study.

As a scientific discipline, phenomenology studies the structure of experience and consciousness. Literally, phenomenology is the study of phenomena, such as apparitions, everything that appears in our experience, the way we experience something, and the meaning we have in our experience. The focus of phenomenology attention is not just a phenomenon, but a conscious experience from the perspective of the first person or who experiences it directly.

Phenomenology seeks to uncover and learn and understand a phenomenon and its unique and unique context experienced by individuals to level of "beliefs" of the individual concerned. Thus studying and understanding it must be based on the point of view, the paradigm and direct confidence of the individual concerned as a subject who experiences first-hand experiences. In other words, phenomenology research seeks to find psychological meaning from an individual's experience of a phenomenon through in-depth research in the context of the daily life of the subject under study.

The focus of the phenomenological approach model is the experience experienced by individuals. How individuals interpret their experiences is related to certain phenomena that are very meaningful to the individual concerned. The experiences discussed here are not just ordinary experiences, but experiences that are related to the structure and level of consciousness of individuals directly or indirectly. Because the phenomenological approach model focuses on individual personal experiences, the research subject is people who experience as first-hand the events or phenomena that occur, not individuals who only know a phenomenon indirectly or through certain media.

Because this research method used is a qualitative research method, the technique of collecting samples uses the method of exposure (where the aim of the study), where the various considerations are carried out, namely based on the theory used, and the direction of the characteristics of the subjects studied.

The research data sources are based on informant and documentation. The subjects in this study were three students who like to do selfie photos from Muhammadiyah University in Sidoarjo Research data itself are based on interview results. The research data collection technics are doing interview in the university, recording the interview, and doing library study to do data classification.

\section{RESEARCH RESULTS and DISCUSSIONS RESULTS}

Selfie phenomenon is a part of culture nowadays. It always happens in everywhere and anywhere. This phenomenon is also happening in Muhammadiyah University of Sioarjo. The researcher has found it several times, so the rearcher has done interviewing three university students who did selfie for several times in university area.

As the results, they do it because they feel that selfie can take their moment as their own memories. One of them also brings selfie stick for taking picture more easily.

Based on Islamic view, doing selfie can be considered as a Haram action, if the selfie followers use it to reveal their aurat for losing dignity and doing it with danger position that can end their life. Yet, in other word, Islam can consider it as Halal action, if the selfie followers use it with proper manner, positive action, and good action to invite and to show positiveness.

\section{DISCUSSION \\ Selfie Culture Exposure}

Definition of selfie ${ }^{1}$ is a selfie or selfie photo (English: Selfie) is a type of self-portrait photo taken by yourself using a

\footnotetext{
${ }^{1}$ Departemen Pendidikan Nasional, Kamus Besar Bahasa Indonesia (Jakarta: Balai Pustaka, 2000), hlm. 321
} 
digital camera or camera phone. $^{2}$ Narcissistic photos are often associated with narcissism, especially in social networks. In the Korean entertainment industry, the term used is selca

(abbreviation for self camera). The pose that is used is generally casual and is taken using a camera directed at yourself, or it can also be through a mirror. The object of this photo is usually only the photographer

or some people who can be reached by the camera's focus. Narcissistic photos involving several people are called group narcissist photos.

\section{The history of selfies}

According to The Vintage News, Tuesday (03/15/2016), selfies have been around since 1839 in the era where photography was first discovered. The first person to take a selfie photo was Robert Cornelius (30), a chemist and pioneer of photography from the United States who produced his image in 1839 .

The resulting photo is a portrait in the middle of the picture (off-center) with arms crossed, slanted and tangled haircut styles, which later became known as portraits of the oldest human photography in the United States. After printing the first selfie photo, he wrote a quote "the first light picture ever taken: 1839" which means "the first light picture ever taken".

Since that time, Cornelius became a famous figure with the Daguerrotype work (a method or process for making photographs) which was first published in the world. In 1841 and 1843 he began operating the first two photography studios in the United States.

A woman who also has Russian nationality, named Anastasia Nekolaevna, was one of the first teenagers to take a photo of herself using a mirror to be sent to her friend in 1914 when she was only 13 years old. Then in the letter accompanying the photo, he said "I took a picture of myself by

\footnotetext{
${ }^{2}$ https://en.wikipedia.org/wiki/Selfiee diakses pada Kamis, 23 Mei 2019 pukul 09.17
}

looking at the mirror. It was very shocking, where my hands trembled.

In 2013, the word selfie was officially listed in the online version of the Oxford English Dictionary, and in November 2013. The Oxford Dictionary was named the Word of the year in 2013, stating that this word came from Australia.

\section{Expert review on selfie}

From the perspective of psychology, a psychologist Kasandra Putranto said that selfie is a matter of supply and demand. Demand when there is someone who wants to display a picture of himself while it is supported by the (supply) sophistication of today's gadgets.

Whereas according to Prof. Sherry Turkie from the Massachusetts Institute of Technology, selfie is like a photo in general that serves to capture a moment that is then shown to others. Experience of Prof. Turkei in studying the relationship between humans and mobile technology for 15 years concluded that people no longer felt themselves to be without sharing thoughts and feelings, even though it was not clear to themselves. He also said that selfie resulted in many people ignoring things that were happening around them because they were more concerned with documenting those moments without missing them.

In the theory of culture explains that culture is the whole system of ideas and tastes, actions, and that produced by humans in the social life that is used as their learning (Koentjaraningrat, in www.kompasiana.com).

The theory above is correlated with the phenomenon of photo-taking style that is currently being rife. Then it could be a photo phenomenon is a culture that has just emerged. As R. Linton's opinion on culture, namely culture can be seen as configuration of behavior learned and results of behavior studied, where elements of formation are supported and forwarded by community members. 
Looking at it from the point of view of psychology about selfie and its consequences, it can be said that there are some effects that arise from selfi itself, both positive and negative. Among others are :

1) Negative Impact

According to research conducted in the United Kingdom, stating that sharing too many photos into social networks including selfies has the potential to worsen relationships or make photographers less favored.

Dr. David Hoogton said that someone who regularly posts his photos on social media is very dangerous in real life, because not everyone is on good terms with the person who posted his personal photo.

2) Positive Impact

According to Psychologist Paggy Dreyler, selfies usually benefit many people when used appropriately. For example, photos after carrying out healthy living habits compared to before.

Meanwhile, according to Rutlegde, if

selfie is done correctly so it can be a way to express yourself and be able to create balance and open your mind to understand.

\section{Selfie phenomenon according to Islamic views}

Phenomenology is a study in the field of philosophy that studies humans as a phenomenon. Phenomenonology in philosophy is usually associated with hermeneutics, which is the study of the meaning of this phenomenon. The term was first introduced by Johann Heinrich Lambert (1728 - 1777), a German philosopher. In his book Neues Organon (1764). he wrote about unreal science.

In a literary approach, phenomenology makes use of the intuitive experience of phenomena, something that is present in phenomenological reflection, as a starting point and effort to obtain the features of the experience and nature of what we experience. G.W.F. Hegel and Edmund Husserl are two important figures in the development of this philosophical approach.

The phenomenological tradition concentrates on personal experience including parts from individuals who have shared experiences with each other. Communication is seen as a process of sharing experiences or information between individuals through dialogue. Good relations between individuals have a high position in this tradition. In this tradition say that language is a representation of things. So, just one word can give meaning to something you want to mean.

Basically phenomenology is a study tradition that is used to explore human experience. As Little John argues that phenomenology is a tradition to explore human experience. In this context there is an assumption that humans actively understand the world around him as a life experience and actively interpret the experience.

The main assumption of phenomenology is that humans actively interpret their experiences by giving meaning to something they experience. Therefore interpretation is an active process to give meaning to something that is experienced by humans. In other words, understanding is a creative action, namely action toward meaning.

\section{Legal basis}

Selfie is a contemporary matter. However, the legal basis for this can be seen from the generality of the word Rasulullah Shallallahu 'alaihi wasallam, ${ }^{3}$

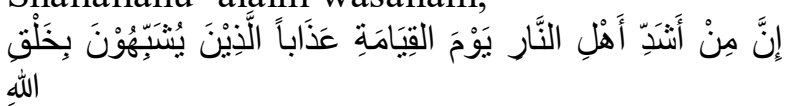

"Indeed, among the greatest adherents on the Day of Resurrection will be those who make things that resemble creation of Allah SWT." (HR. Muslim)

Imam Muslim narrated from Ibn Abbas, he said, "I heard Abu Talha said,' I

\footnotetext{
${ }^{3}$ Muslim bin Hajaj An-Naisaburi, Shahih Muslim (Beirut: Dar Al-Kotob Al-Ilmiyah, 2011), jild. 3, hlm. 384, Kitab Libas, no. Hadits 2107
} 
heard Rasulullah Shallallahu 'alaihi wasallam bersabda, ${ }^{4}$

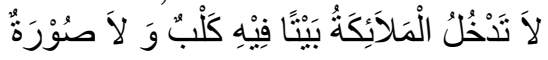

"Angels will not enter the house where there are dogs and pictures." (HR. Muslim)

Imam Al-Khathabi commented on the hadith above, "What is meant by not entering an angel into a house because of the existence of a dog and the picture in it is a house that has a dog or an image that is indeed forbidden to have. That is, if the house is a dog that is not haram owned like a dog for hunting, or to look after plants and livestock, likewise the image in its as a picture (which is not unclean) which is had in a despicable place, such as on a carpet (which is trampled), on a pillow (which is occupied) and besides, then that does not prevent angels from entering the house. "

According to the Islamic view the phenomenon of selfi is not directly written in the book of the Koran and the hadith, so different laws emerge. Following are some Islamic views about the selfie phenomenon:

a. The law of selfi is haram

The first law of selfie is "unclean". This is based on the Riwatar Tirmzi hadith which tells the story of how the Messenger of Allah, may Allah bless him and grant him peace, forbade him to put pictures in the house and at the same time explain the prohibition on making pictures. In the hadith it reads:

"Your Majesty Muhammad SAW forbade the image to be inside the house and he also forbade making pictures" (HR Tirmizi).

Selfie photos themselves are included in what is meant in the hadith. Because selfie is a picture of living things that are not permissible in Islam. This is because in a selfie photo clearly shows the face or even the body of a living being.

In addition, a story also tells how long ago the angel Jibil did not want to enter the house unless the owner of the house had

${ }^{4}$ Wahbah Az-Zuhaili, Fiqih Islam wa Adillatuhu

(Jakarta: Gema Insani Prees, 2016), jild. 4, hlm. 228 removed the statue's head which was the decoration of the house. Because of the head statue has characterized the image of a living being who has an absolute soul and soul. In the hadith it reads:

"(Characteristics) the image is a head, the head (image) is removed, it is no longer said to be a picture." (HR al - Baihaqi). ${ }^{5}$

Regarding the validity of the hadith, Syeh Al Albani has said that the hadith above is valid and undoubtedly the truth. In addition to pictures, video self-organization is

also legal. Because both displays the limbs even in the video more clearly because the image can move.

Apart from the explanation above, there are also other things that cause the selfie to be forbidden, for example because the intentions or wrong objectives include:

1. To show off

2. To harm others

3. To hurt yourself and others

4. For sheer lust

5. To fight and divulge the secrets of yourself and others

\section{b. Allowance of Selfie law}

The second law of selfie is "may". Some scholars allow the law of selfie photos to be reviewed from an Islamic perspective. This is because in taking selfie photos the tools used are in the form of cameras while in the narrations of the Prophet's history defines prohibited images as images of living creatures created using human hands with the aim of resembling their original form. This means that selfies are only done by "capturing / photographing" and not "creating" new things that resemble living things.

Regarding this matter one of the Muslim scholars alumni of the State Islamic University (UIN) Walisongo gave a more specific explanation that: "The images and photos are identical but not the same. If the picture referred to at the time of the Prophet painted by trying to imitate the original form,

\footnotetext{
${ }^{5}$ Wahbah Az-Zuhaili, Fiqih Islam wa Adillatuhu (Jakarta: Gema Insani Prees, 2016), jild. 4, hlm. 228
} 
then the photo in modern times is just capturing the object image at a certain moment and time through the process of taking light. So, the selfie photo is not included in the category referred to in the hadith. But, there is a distinctive impact on selfies, especially when uploaded into social media and being seen by lots of people,"

Selfies also have signs that need to be obeyed. Among these signs are:

1. Keep the aurat

Maintaining aurat is obligatory for every Muslim in every circumstance. Someone who has a selfie is still obliged to maintain his nakedness, even though the photo is stored for himself. This is to protect themselves from incidents that occur beyond the possibility.

2. Not tasyabbuh by posing for the style of infidels

When selfie, a Muslim is required to maintain a style or pose so as not to overdo it, even resembling an infidel, because this includes tasyabbuh action. The Prophet said,

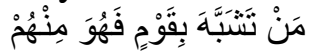

"Whoever imitates a people is part of them." (Narrated by Abu Dawud)

3. Don't upload it on social media

Uploading photos on social media is a temptation for selfie fans. As a Muslim, especially women, this is clearly not something ethical, even causing slander, remembering everything about woman's body is being captured as an attraction. There will be a lot of mafsadah (damage) that will be caused if the woman uploads her selfies on social media, even mafsadah here is qath'i (certain). This is also contrary to the word of God,

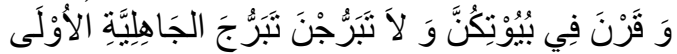

"And let you remain in your house and do not decorate and (behave) like the ignorant people first ..." (Surah Al-Ahzab: 33) ${ }^{6}$

According to Dr. Wahbah Az-Zuhaili verse above shows the prohibition of the

\footnotetext{
${ }^{6}$ Bukhori, Al-, Muhammad bin Ismail bin Ibrahim, Shahih Al-Bukhori Riyadh: Bait Al-Afkar, 1998
}

release of women except for a need. The word tabarruj in the verse means revealing jewelry, as well as showing beauty in front of men. The order to stay and the prohibition to decorate in this verse are then clarified by uploading a photo because there are elements of displaying themselves with improper makeup or poses.

With this, the law of uploading photos for women is unlawful. This is also viewed from a fiqh rule that reads, ${ }^{7}$

$$
\text { الضَّرَرُ يُزَ النُ }
$$

"A mudharat must be removed."

As for uploading photos for groups that are indeed not forbidden for considered, then it may, provided that it does not contain Mudharat.

This is based on the words of Shaykh Muhammad Al-Hasan Walad Ad-Dadu AsSyinqithiy,

"And what can be viewed directly, then may save the photo for any purpose."

4. Don't make it a lifestyle

Selfies that are too often can lead one to two reprehensible traits, namely 'Ujub and takabbur. When a selfie, he or she admires the results, but it means that he admires himself, then that means 'Ujub. Likewise, if the selfie actor then compares his picture with someone else, then feels himself better than that person, then he falls on the takabbur. The Prophet said,

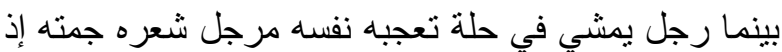
خسف الله بأ, فهو يتجلجل في الأرض إلى ئل يوم القيامة

"When a man walks in the robe that he wears, he admires himself, then he is swallowed up (by the earth), so he will still shake (in the bowels of the earth) until the Day of Judgment comes."

(Narrated by Bukhori)

If someone who has a selfie has ensured that he is still permanent in the corridor, then selfie returns to the original

\footnotetext{
${ }^{7}$ Tanasa, Endzico Januar. Studi Kualitatif Motif dan Kepuasan Penggunaan Foto Selfie Dalam Akun Instagram. Surakarta: Universitas Sebelas Maret. 2015
} 
law, which is permissible, as permitted by photography.

This is based on rules itself:

$$
\begin{aligned}
& \text { إِذَا زَالَ الْمَانِعُ عَادَ الْلَمْنُوُْعُ, } \\
& \text { "If those who forbid have been lost, } \\
& \text { those who are banned will return." }
\end{aligned}
$$

\section{RESEARCH CLOSING}

The phenomenon of selfie that is lively among the people is what then invites controversy regarding the law of his ability. So that selfie seems to be a new culture that is welcomed by the community because it is considered as a cool style and one way to get existence in the eyes of others. This problem then prompted the writer to explain the law regarding selfie.

From the statement above it can be concluded that the tradition of phenomenology focuses its attention on the conscious experience of an individual. The tradition of phenomenology places very strong emphasis on the perceptions and interpretations of human subjective experience.

This phenomenon of selfie happened because of the technological developments were so extraordinary. If in the past the photos of self were not possible because of the lack of capable and supportive technology, now there are many tools that support such as gadgets or cell phones for selfies.

In addition, this research can provide benefits as scientific insights for personal writers, as a contribution of scientific work to other researchers, and as a contribution to the development of science for academics and society in general.

Moreover, this research has some data collection technics that is done by the researcher through doing interview on the spot in Muhammadiyah University of Sidoarjo. The rearcher asks three university students, then recording the interview process, and last of all, the researcher is doing library study to do data classification. Therefore, the research data can be valid as the data collection in this research.

\section{E. RESEARCH CONCLUSION AND SUGGESTION \\ Conclusion}

The law of selfie is permissible as long as a Muslim remains in the prevailing corridor of the Shari'ah. Moreover, Muslims must be aware of norm, culture, and also condition that relates to Islamic law.

Based on that, doing selfie also is a part of culture that can be used for inviting and sharing about Islam to anyone in anywhere.

\section{Suggestion}

As a Muslim, it is appropriate for us to be careful in carrying out an act. Among the precautions that we have to guard is in the matter of selfie. As a Muslim should not overdo it in selfie especially to open and uncover clothes when they have to do it. As a Muslim must know how to behave and stay in good manner to be as good Muslim based on Al-Qur'an and also Sunnah Rasulullah S.A.W. As a Muslim needs to act carefully when they find some spots to be the selfie background. They do not have to be overacting and make a huge risk of their lifes. Selfie also can be used for doing campaign, promoting something, and can be used to share Islamic Dakwah to anyone through social media. Yet, the selfie followers must be aware and share positive action in positive way and also based on Islamic culture.

\section{F. REFERENCES}

Alqur'an Al-Karim dan terjemahnya. Bandung: Syamil Qur'an

Bukhori, Al-, Muhammad bin Ismail bin Ibrahim, Shahih Al-Bukhori Riyadh: Bait Al-Afkar, 1998

Departemen Pendidikan Nasional. Kamus Besar Bahasa Indonesia. Jakarta: Balai Pustaka. 2000

Moustakas, C. Phenomenological Research Methods. London: Sage. 1994. 
Naisaburi (al), Muslim bin Hajaj, Shahih Muslim (Beirut: Dar Al-Kotob AlIlmiyah, 2011), jild. 3, hlm. 384, Kitab Libas, no. Hadits 2107

Schutz, A. ed H R Wagner. On phenomenology and Social Relations. Chicago: Chicago University Press. 1970.

Tanasa, Endzico Januar. Studi Kualitatif Motif dan Kepuasan Penggunaan Foto Selfie Dalam Akun Instagram. Surakarta: Universitas Sebelas Maret. 2015

Zuhaili, Az-, Wahbah. Fiqih Islam wa Adillatuhu. terj. Abdul Hayyie AlKattani dkk. Depok: Gema Insani. 2016.

Fiqih Islam wa Adillatuhu (Jakarta: Gema Insani Press, 2016)

http://www.duniaislam.org/19/02/2015/penge rtian-dan-hukum-selfiee-dalam-islam/ diakses pada hari Rabu, 22 Mei 2019 pukul 12:18

https://en.wikipedia.org/wiki/Selfiee diakses pada Sabtu, Kamis, 23 Mei 2019 pukul 09.17. 